\title{
Pedagogical Management of University Students' Communication Ability Development
}

Spirchagova Tatiana Anatolievna

Kazan (Volga) Federal University, Russia, tatianasp@nm.ru

Nasyrova Albina Munirovna

Kazan (Volga) Federal University, Russia, to.albina@gmail.com

Vakhitova Dilyara Kasimovna

Kazan State University of Architecture and Engineering, Russia, dilik15@yandex.ru

Sadrieva Liliya Mirzayanovna

Almetyevsk oil Institute, Russia, lia-agni@mail.ru

Brodskaya Tatiana Anatolievna

Almetyevsk oil Institute, Russia, tatyana.brodskaya72@mail.ru

The development of social interaction forms emphasizes urgency and importance of the topic. The purpose of the study is to find out peculiarities of pedagogical management of university students' communication ability development. The leading approach to the research was the narrative approach which allows considering pedagogical management of communication ability development as the process of creating conditions for successful social psychological adaptation and effective interaction with other people. The research results are the identification of pedagogical management methods (role-personality, exercise ("etude"), diagnostic, training) and their effectiveness criteria. The findings revealed active cooperation arrangement and skills development: to perceive people, assess them adequately, empathize, understand; keep the steady state of the individual self. A test "Do we know how to listen" and other training exercises were developed for the research.

Keywords: pedagogical management, narrative approach, education impact, university, higher education

\section{INTRODUCTION}

The development of social interaction forms emphasizes urgency and importance of the topic. Communication ability is one of the most socially determined types of abilities, which includes the ability to perceive people, assess them, achieve mutual

Citation: Anatolievna, S. T., Munirovna, N. A., Kasimovna, V. D., Mirzayanovna, S. L. \& Anatolievn, B. T. (2017). Pedagogical Management of University Students' Communication Ability Development. International Journal of Instruction, 10(3), 79-92. https://doi.org/10.12973/iji.2017.1036a 
understanding, and influence others (Rakhmetova et al., 2002). Communication ability requires the ability to behave in accordance with social norms, i.e. requirements, regulations and expectations of such behavior so that the person could be taken and understood by other people (Orekhovskaya et al., 2016).

Communication is a process, which includes such elements as communication, interaction and perception. Communication is the most important determinant of the entire personality development system. A person perceives another person's "inner world" in the communication process. However, this process requires a particular "inner world" of each participant. Thus, communication is a specific information exchange, the process of sending emotional and intellectual information to the recipient. The person, whose purpose is to have some influence on the recipient, sends a certain message. The message may be encoded be means of verbal (words) and nonverbal (body language, mime, gestures, intonation, symbols, etc.) signs. The recipient must decode the message to understand the information. Consequently, a complete single communication cycle contains successive moves of the partners. Communication contact can be expressed in a statement, question or inducement, concealing or demonstrating motives. Communication always has a particular situational character which is determined by the relations between the participants (Shaidullina et al., 2015).

The next part of communication is interaction. It is the arrangement of cooperation between people. The main participants of this process are people themselves, their connection and influence on each other, suggesting mutual changes. To make the interaction process effective and dialogic, it is necessary to follow certain conditions: the equality of people's psychological positions irrespective of their social class; equality in the recognition of active communication role of each other. The third part of communication is perception (from the Latin peruptio - psychological perception). Perception is a perceptual process, which promotes mutual understanding between the communication participants and aimed at the achievement of the following objectives: formation of the content of interpersonal perception; promoting mutual understanding; providing the participants' influence on each other. It was found that the perception of social objects has the following specifics: the person who is perceived tends to transform his self-image in a favorable way for his own purposes; the attention of the person who perceives is focused on conceptual and judgment based on (including causative) interpretation of the object; significant dependence on motivating and conceptual activity and its relation to the affects. This information keeps up to date the need for pedagogical support of university students' communication ability development. Pedagogical management should be understood as the activity that provides the subject with conditions for best decision in different situations of life choice (Petrova et al., 2016; Yepaneshnikov et al., 2016).

Successfully organized pedagogical management helps a person to enter the "development zone", which it is not available to him yet. The aim of the research is to find out peculiarities of pedagogical management of university students' communication ability development. 


\section{METHOD}

The leading approach to the research was the narrative approach which allows us to consider pedagogical management of communication ability development as the process of creating conditions for successful social psychological adaptation and effective interaction with others. Narrative approach is based on the idea that people's relations are formed in the process of social interaction. Narrative approach emerged in the late XX century, when Michael White and David Epston published the book "Narrative means to therapeutic ends" (White \& Epston, 1990). Since then it came to the notice of professionals around the world. It has been developing in Russia since 2000 (Doan, 1998; Douge, 2010; Etchison, \& Kleist, 2000; Freedman, \& Combs, 1996; Grimwade, 2009; Hin Kong et al., 2011; Kutuzova, 2007; Pavelka, 2014; Ustaomeroglu et al., 2015; White, 2010; Winslade \& Monk, 2000).

According to the narrative approach, the understanding of the events in our lives comes from the stories we tell each other and ourselves. The same story can be told from different points of view, and the way it is done will affect the perception, evaluation of what is happening and a person's following actions. This suggests that the units of communication are cycles, which show the relations of positions, attitudes, each participant's points of view and intertwine direct communication and feedback in the flow of circulating information. This is due to the fact that in the process of communication, in the dialogue views are shared, creating something whole in the linguistic (speech) communication. Every communication cycle begins with the identification of the problem, which arises in the process of interaction and ends with individual decisions coordination. The sequence of cycles is not determined by the preformed programme or plan outlined beforehand. It is very mobile and directed by the course of joint activities. An important aspect of the communication process is coordination of actions carried out by the participants in time, synchronization of psychological processes and states in particular. In conditions of the joint activity even synchronization of physiological processes (e.g. pulse) sometimes occurs.

In the final cycle of the communication process the coordination of interaction results, their control and correction are carried out, common positions of the participants are developed. It is particularly reflected in the coordination of ideas, concepts, solutions, principles and strategies of joint activities formed in the process of communication. The specific dynamics of the communication process, the structure of cycles and their sequence depend on the topic of communication and distinctive features of people participating in it. Narrative approach allows to make the following connections in the process of creating conditions for successful social and psychological adaptation and effective interaction with others: 1) effectiveness of pedagogical management of communication ability development increases upon condition that each participant of the interaction maintains independence and ensures self-regulation of his communication activities; 2) effectiveness of the interaction with others increases upon condition that there is a possibility to distribute the functions between the participants, role reversal in the course of solving problems; 3) success of social and psychological adaptation increases upon condition that there is information and activity exchange, demonstrating 
the attitude to each other (assistance, sympathy, empathy, cooperation). The main research tools are observation, interviews, questionnaire.

\section{Study Group}

The study group of this study consists of 300 teachers, 500 students of Kazan Federal University to identify the criteria. In this study, as one of the purposive sampling methods, criterion sampling method was used.

\section{FINDINGS}

The main results of this research were the methods of pedagogical management of communication ability development (role-personality, exercise ("etude"), diagnostic, training) and their effectiveness criteria.

\section{Pedagogical management methods}

It was found out that role-personality methods involve performance of different social roles by students (lecturer, expert, moderator and others). In real life, we meet the interaction of different types: 1) individual-personality, "I - I" (for example: teacher student, chief - subordinate); 2) individual-collective, "I - We" (the chief - staff); 3) collective-public, "We - We" (administrative management personnel of the company and staff). Role-personality methods contribute to the development of different interaction types and verbal communication types (social and inner speech, dialogue and monologue, speech and writing, unreflective and reflective listening) (Sadovaya et al., 2016; Zamaletdinov et al., 2016).

Exercise ("etude") methods involve the discussion process of proving or substantiating, creative imagination process, search for solution by improvisation in the given circumstances. The Russian word "etude" has different meanings: 1) the product of auxiliary character (drawing, painting or sculpture), usually of a small size, made from life; 2) instrument theatrical piece of virtuoso character for concert performance; 3) the small work of literature or research on any particular issue; 4) exercise for the development and improvement of any art technique (acting, chess, music, etc.). In teaching practice exercise ("etude") methods involve problem statement, task definition for its solution, creation of conduct rules (cans and cannots). The discussion process involves all students: some of them as performers, others as observers, which were originally given the role of supervisors. It not so important how the performers "acted", but the important thing is what the observers saw. In a simple exercise ("etude") made by friends they can see a lot of new ideas and problem solutions, which the performers do not guess or think. This competitive process of information interchange used in the exercise ("etude") allows students to get into a reflective position (Pugacheva, Ezhov et al., 2016). Reflection here provides for the mutual imaging of participants in several positions: performers, as they see themselves and what they did; performers and what they did as seen by observers; and the same positions, but as seen by another person. There is a mirror image of each other's activities.

The group of diagnostic techniques is well known to researchers. Diagnostic techniques include a series of similar short standardized tests of the person having certain abilities. 
The net result of these tests gives an idea of the individual's measured ability level (by means of the test score calculation). The group of methods "Training" is aimed at developing skills to elaborate a cooperation strategy and focusing on conceptual perception by other people.

\section{Effectiveness criteria of pedagogical management methods}

The experimental test on the effectiveness of methods was carried out from 2014 till 2017 in three stages: summative, formative and control. At the summative stage a special programme was developed to implement pedagogical management methods in teaching practice. At the formative stage the programme was implemented. The following topics of seminars were developed to test the effectiveness of role-personality methods: "Culture and technique of speech", "Technique of speech: breathing, voice, diction, rhythm", "Spoken word in the range of communication modes and methodology of its use", "Persuasion as basic method of communicative influence", "Suggestion as a way of influence", "The role and place of evidence in speech", "Public speaking and methodology of preparation for it: goal set, its development method, material collection, speech plan and text; skills in self-management, basics of self-control technique, appearance, basics of mimic and pantomimic expressiveness". In the process of preparation and conduct of classes the students performed different roles. It provided knowledge internalization, development of skills to perceive people, assess them adequately, empathize, and understand. This allows achieving effective interaction with people, behavior which meets social norms, information exchange, developing the person's administerial and communication skills.

To test the effectiveness of exercise ("etude") methods the following exercises ("etudes") were used. It was suggested to arrange the exercise ("etude") "Dance floor" for the development of the administerial and mutual understanding skills in the process of joint activity. Six-eight people participated in this exercise ("etude"). Possible options for the task: a) the partner is much taller than her, she has attractive appearance; b) partners are very tall who are on the dance floor for the first time; c) a married couple (husband and wife) had an argument while dancing; g) loving couple: he is very short, she is tall, thin, non-stop dance; d) the partner in a new suit, timid, she is overweight, cheerful and so on. Creating the atmosphere of a "dance floor", trick ending, emotional richness were assessed in the exercise ("etude").

The exercise ("etude") "Photo" is suggested for the development of intuition, the ability to perceive and understand a person. Each student was asked to consider five photographs of age mates. People depicted in the photographs were engaged in different activities. The student's task was to choose the common name for all five photographs and describe the depicted people. It was required to characterize personality in general rather than some parts of his face. The students picked up at least ten adjectives which describe the character and state of each person in the photograph. For example: calm, sociable, quiet, simple-minded, friendly, plain, agreeable, funny, tired, sad, etc.

The exercise ("etude") "Telephone" is suggested for the development of the ability to keep the attention of the conversation partner. The participants were asked to talk to an 
imaginary conversation partner: 1) mother who they have not seen for a long time or friend who they offended (it was assumed that the conversation would be emotional); 2) a stranger in order to make an inquiry or to advertise something (for example, asking a theater manager for a ticket).

The exercise ("etude") "Dialogue without words" is suggested for the development of the ability to think in efficient, eventful terms. The participants were asked to make an exercise ("etude") on the following topics: "First date", "Refusal", "Surprise", "Contact", "Secret deal", "Blackmail", "Deception", "Offence", "Joke", "Gossip", "Choice", "Incident", "Kitchen", "End", "Recognition", "Secret". Two or three students participated in this exercise ("etude"). The exercise ("etude") must have: introduction, climax, denouement of the story. Originality of the plot, trick ending, emotional richness, theme development were assessed positively in the exercise ("etude").

The following exercises were suggested for the development of ideomotion (ideas about motion performance leading to real simulation): 1) "Warm-up": stretch oneself in different directions; try to cover as much space as possible. The energy used during the exercise was assessed (movement amplitude, facial gesture); 2) "Get to conversation partner": standing still a person should get by hand and draw to himself the chosen participant who stands at the other end of the room. The energy of the activity and sense of proportion were assessed; 3) "Imagine you are on the take-off site" (river bank, roof of the house): after catching the rising airflow with extended hands the student should "take off" (on the principle of a glider). The success of the exercise depended on the motional ideas and coordination. "Take-off" and "touchdown" time was assessed; 4) "Bundle of energy": the students were asked to imagine that they were holding ball in the left / right hand. The task was to move it from one hand to the other and backward. Motional reaction was assessed: the imaginary object took shape in micromovements, and the viewer could say with confidence, where the "ball" was at that moment; 5) "Good luck": the student was asked to take as much "happiness" and "luck" as possible from the space. In this exercise the feeling of faith, activity, emotional excitement were assessed on the basis of movement amplitude and involvement in the task. The word "ideomotion" comes from the Greek word idea - "image" and Latin motor - "moving". Ideomotion act is explained as the appearance of nerve impulses, providing any movement in the idea of this movement. Ideomotion training methods are commonly used by athletes when they mentally imagine complex combinations of movements bringing them to perfection which are to be carried out. However, in the process of communication ability development ideomotion exercises ensure the development of imagination, visualization, visual images, non-verbal communication.

Diagnostic techniques were widely used. We will give just one example: "Do we know how to listen". The objective is a self-test in listening skills. Note: put " $\mathrm{X}$ " on the numbers of the statements that describe situations that cause you frustration, disappointment or irritation with anyone in the conversation. 1. The conversation partner does not give me a chance to speak, I have something to say, but cannot get a word in. 2 . The conversation partner interrupts me constantly during the conversation. 3. The conversation partner never looks in the face during the conversation, and I'm not sure if 
I am being listened to. 4. Talk with the partner who does not look in the face during the conversation, often causes the feeling of wasting time, because it seems that he is not listening to me. 5. The conversation partner constantly fusses: he is more interested in other things rather than my words. 6 . The conversation partner never smiles. I have feeling of tension and anxiety. 7. The conversation partner constantly distracts me with his questions and comments. 8. Whatever I say the conversation partner always throws cold water on me. 9. The conversation partner is constantly trying to reject me. 10. The conversation partner juggles with my words and puts a different meaning in them. 11 . When I ask a question, the conversation partner makes me act on the defensive. 12. Sometimes the conversation partner asks me again, pretending not to hear. 13. The conversation partner, without listening to the end, interrupts me just to agree. 14. The conversation partner when talking is engaged in other activities: playing with a pen, wiping his glasses, etc., and I am absolutely sure that he is inattentive at this time. 15. The conversation partner draws conclusions for me. 16 . The conversation partner always tries to get a word in my story. 17. The conversation partner is looking at me very carefully without blinking. 18. The conversation partner looks as if assessing me. It concerns me. 19. When I offer something new, the conversation partner says that he thinks the same way. 20. The conversation partner overplays showing that he is interested in the conversation, too often nods, gasps and says yes. 21. When I am talking about something serious, the conversation partner gets in various stories, jokes and anecdotes. 22. The conversation partner often looks at his watch while talking. 23. When I speak to him at the meeting, he drops everything and looks at me attentively. 24. The conversation partner behaves as if I prevent him from doing something very important. 25. The conversation partner requires you to agree with him. Any his statement ends with a question: "Do you also think so?" or "Don't you agree?"

Test results processing. Calculate the proportion of marked situations in percentage points of the total number. If it is in the range from 70 to $100 \%$ (18 or more statements) it means that you are a bad conversation partner. You should work on yourself and learn to listen. If it is in the range from 40 to $70 \%$ (10-17 statements) it means that you have certain disadvantages. You are critical about the statements of the conversation partner, and you still lack some advantages of a good listener: avoid jumping to conclusions, do not concentrate on the manner of speaking, do not pretend, look for the hidden meaning of what has been said, do not monopolize the conversation. If marked situations range from 10 to $40 \%$ (49 statements) it means that you can be considered a good conversation partner, but sometimes you refuse partner in full understanding. Try to repeat his statements politely, let him expand his thoughts completely, adapt your thinking speed to his speech, and you can be sure that it would be even more enjoyable to communicate with you. If you scored $0-10 \%$ (up to three statements) it means that you are a great conversation partner. You know how to listen. Your communication style can serve an example to others.

In the process of the training arrangement a wide range of exercises was used. We gave the examples of exercises below. Exercise 1. What words and actions will you use to overcome the following barriers of communication: 1) the conversation partner pays more attention to your appearance (clothes, hair); 2) the conversation partner does not 
believe that he will hear something which is new and interesting in your opinion; 3) the conversation partner expresses views that contradict yours; 4) the conversation partner communicates outdated information, thinks about some other problems during the conversation; 5) the conversation partner pays greater attention to your disadvantages; 6) the conversation partner tends to give a hasty assessment of the information which was not given to the full extent; 7) the conversation partner has negative emotions because of the divergence of the arguments; 8) the conversation partner's behavior is too self-confident during the conversation; 9) the conversation partner takes staunch stand. Exercise 2. Find the reason of the conversation beginning: Excuse me, am I disturbing you? I would like to hear once again. Please, do you have time to listen to me? Let's consider it quickly with you. I was just passing by and dropped in to you. I have a different opinion on that. I would like to discuss with you .... I think this problem is of particular importance to you. Exercise 3. "Communication of emotions". The participants were placed in a circle. The first participant was asked to send his negative emotions to his neighbor on the right using one or two phrases. The second participant without responding to the first person "sent" the received negative emotions to the next neighbor. The third participant also did not respond to the offender and using one or two phrases sent the emotions to the next person in chain order. When the game got a circle, the rules of the game changed. The first participant using one or two affable phrases shared his good mood with a neighbor. The second person after getting positive emotions sent them to the third participant and so on. Thus, positive emotions were involved. This exercise gave the opportunity to compare positive and negative emotions. The objective criteria for successful performance of the exercise were: 1) the student's involvement in the situation; 2) emotional speech, which was assessed using the tape recording. The number of emotional exclamations, sentence length, word order in the sentence were registered.

The following exercises were suggested for the development of image thinking, imagination, non-verbal communication. The first is "Sounds and impressions". Students were asked to listen to a series of different sounds and talk about the images and associations that appeared while listening to the recording, combining them into a single story. If necessary, students could listen to the record of sounds twice. The response preparation time was limited ( 3 minutes). High scores were given for the story which was made in a logical way, unusual and unexpected associative bonds, emotional richness. In addition to image thinking, observation, the ability to event-related efficient and space-temporal perception were identified in this task. The second is "Fable without words". The participants were asked to show the fable without using words in different genres (tragedy, vaudeville, western, detective, lyrical drama). In addition to the ability to think in efficient, eventful terms, space-temporal, associative and imaginative perception, imagination and fancy, sense of humor were assessed in the task. The third is "Inner monologue". The participants were asked to consider five photographs depicting people in various situations. The task was to make the inner monologue of people depicted in the photos. The originality of inner monologue, compatibility of the emotional state of people with the situation, the number of interesting and unexpected 
details in the monologue were assessed positively. In addition to the ability to think in efficient, eventful terms, the task develops the ability to analyze and synthesize.

At the control stage by means of questionnaire survey among university teachers and students, the effectiveness criteria of pedagogical management methods of communication ability development were found out: 1) the willingness of students to socially-oriented and person-centered communication; 2) students' knowledge of types (conversation, discussion, interview, argument, etc.) and etiquette of verbal communication; 3) the ability of students to communicate by means of (a) sign systems psychologically equivalent to the language (sign language); (b) secondary sign systems based on the language; (c) contextually comprehensible material objects (for example, a gift sent by mail); 4) the ability of students to listen; 5) students' satisfaction with communication: (a) initiated activity, striving for action (the need for stimulation); (b) social interest is developed (need for recognition); (c) goal achievement, success of communication (need for achievement and acceptance).

\section{DISCUSSION}

The analysis of professional literature showed that pedagogical management is the subject of many researches. However, there is no common understanding of its subject matter. The authors understand pedagogical management, firstly as the direction and technology of a teacher's activity (Yepaneshnikov et al., 2016); collaboration and cooperation without pain or problems (Kamasheva et al., 2016).

Secondly, as the system of professional activities that provides conditions for successful adaptation of a person to living environment (Pugacheva, Kirillova et al., 2016); integrated method of providing conditions for decision-making which is based on the responsibility of a person for making the decision (accompanee has only advisory rights), interest priority of the accompanied person and continuity of support (Pugacheva, Filippova et al., 2016; Terentyeva, Mukhomorova, Perezhogina et al., 2016; Terentyeva, Starodubtsev, Timonin et al., 2016).

Thirdly, as the process of concerned observation, counseling, personal involvement, encouragement of the student's maximum independence in the problem-based situation, the ability of the teacher to support in the individual educational route, individual advancement in learning (Sadovaya et al., 2016); the process where a teacher and a student determine his interests, goals, possibilities and ways of overcoming obstacles which prevent him from keeping his human dignity and achieve independently targeted results in education, self-education, lifestyle (Lunev, Pugacheva \& Stukolova, 2014; Lunev, Safin et al., 2016).

The advantage of all researches in pedagogical management is the idea of the leading role of a teacher, collaborative activities of a teacher (more educated person) and a student (less educated), which reflects the need for mutual dependence of both a teacher's and a student's activities, "it helps to understand the integrated unity of the two activities, turning them into a single" process. However, excessive regulatory student's activity does not promote the development of his internal activity, restrains the initiative. A teacher and a student depend on each other. The student's dependence on a teacher is 
expressed in the fact that he cannot solve the problem himself and needs help. The teacher is dependent because he cannot solve the problem for a student, at the same time without depriving him of the conditions for independence development. Thus it makes possible to interpret the essence of pedagogical support as "warn and teach". It allows speaking of the pedagogy of success aimed at the student's development of independence, self-confidence, the ability to cooperate with other people, "to become a personality".

\section{RECOMMENDEIONS}

The first peculiarity of pedagogical management of university students' communication ability development is the use of special methods (role-personality, exercise ("etude"), diagnostic, training) at classroom studies (lectures, seminars, etc.) and management of extracurricular activities. The methods are simple and do not require special equipment. Only one thing is necessary for their application: the teacher's desire to develop students' ability to communicate. The identified group of methods is based on: 1) verbal-subject impact on students' minds to promote desire for socially-oriented and person-centered communication; 2) verbal-image impact to create the ability to communicate by means of sign systems and images, mastering the etiquette of verbal communication; 3) active cooperation arrangement aimed at the development of the ability to listen, understand each other, mastering verbal communication types, interpersonal sensitivity training. This group of methods provide the development of all structural principles of the communication process (communicative, interactive, perceptive) and contribute to the development of communicative and good managerial skills of a person. The second peculiarity of pedagogical support of communication ability development is to keep a steady state of the students' individual self: awareness and assessment of themselves as partners of communication.

The results allow outlining directions for the future research of the problem which is related to the development of specific programmes of pedagogical support for students in the process of communication ability development. The data of this research may be useful for managers and university teachers; training and professional development centre staff in selecting and structuring the content of university teaching staff advanced training.

\section{REFERENCES}

Doan, RE., (1998) The king is dead: Long live the king: Narrative therapy and practicing what we preach, Family Process, 37(3), 379-385.

Douge, J., (2010). Scrapbooking: an application of narrative therapy. Procedia - Social and Behavioral Sciences, 5, 684-687.

Etchison, M., \& Kleist, DM (2000). Review of narrative therapy: Research and review. Family Journal, 8(1), 61-67.

Freedman, J., \& Combs, G., (1996). Narrative Therapy: The Social Construction of Preferred Realities. New York: Norton, 305 
Grimwade, J., (2009). In praise of sneaky poo: a case, four whites, and a missing narrative. Australian and New Zealand Journal of Family Therapy, 30, 2, 109-121.

Hin Kong AP, Whiteside JD \& Raino A. (2011). Spontaneous recovery of linguistic, narrative, and cognitive skills from bilingual aphasia in Cantonese and English: A case study. Procedia - Social and Behavioral Sciences, 23, 20-21.

Kamasheva, YL, Goloshumova, GS, Goloshumov, AY, Kashina, SG, Pugacheva, NB, Bolshakova, ZM, Tulkibaeva, NN \& Timirov, FF (2016). Features of vocational education management in the region. International Review of Management and Marketing, 6 (1),155-159.

Kutuzova., D.A., (2007). Narrative approach in educational psychology. Journal of practical educational psychology, 3, 109-112.

Lunev, AN., Pugacheva NB., \& Stukolova, LZ., (2014). Development strategies for professional educational services under the increasing autonomy of territories within the federal state. Actual Problems of Economics, 160 (1), 215-220.

Lunev, AN, Safin, RS, Korchagin, EA, Sharafutdinov, DK, Suchkova, TV, Kurzaeva, LV, Nikishina, SR \& Kuznetsova, NA (2016). The mechanism of industrial educational clusters creation as managerial entities of vocational education. International Review of Management and Marketing, (6), 2S, 166-171.

Orekhovskaya, NA., Lavrentiev, SY., Khairullina, ER., Yevgrafova, OG., Strakhova, IV, Sakhipova, ZM., Khlebnikova, NV., \& Vishnevskaya, MN., (2016). Management of young professionals success in the labor market. International Review of Management and Marketing 6,(2), 264-269.

Pavelka, J., (2014). Narratology as an interpretative model, and a narrative analysis as an interpretative key of basic teaching tools in textbooks and in data-video presentation. Procedia - Social and Behavioral Sciences, 141, 934-939.

Petrova, TN, Kirillova, OV, Sokolova, SG, Pugacheva, NB, Galimullina, AF, Maksimova, OG, Antonova, TV \& Kozhanov, VV (2016). Education as the management of research universities students' socialization. International Review of Management and Marketing, (6), 2S, 28-33.

Pugacheva AS, Filippova VP, Kon AY, Dorzhieva LB, Silchenok IS, Pugacheva NB, Lunev AN, Mustafina AA (2016). Market regulators of service spheres innovative development as a tool of regional socio-economic policy. International Review of Management and Marketing, (6), 2S, 294-300.

Pugacheva, NB, Kirillova, TV, Ovchinnikova, IG, Kudyashev, NK, Lunev, AN, Pavlova, OA, Kashina, SG \& Valeyev, AS (2016). The mechanism of state-public management of vocational education in the region. International Review of Management and Marketing, (6), 2S, 6-11.

Pugacheva, NB., Ezhov, SG., Kozhanov, IV, Kozhanova, MB., Ogorodnikova, SV., Oshaev, AG., Timonin, AI., \& Goloshumova, GS., (2016). The model of self-realization 
readiness formation of research universities students in the process of civic education. International Review of Management and Marketing, (6)1, 128-133.

Rakhmetova, N., Urazalieva, M., Baitukayeva, A., \& Baitukayeva, D., (2015). Communicative abilities formation in modern pedagogical science. Procedia - Social and Behavioral Sciences,(190), 305-308.

Sadovaya, VV., Korshunova, OV., \& Nauruzbay, ZhZh., (2016). Personalized education strategies. Mathematics Education, 11(1), 199-209.

Shaidullina, AR, Maksimova, OG, Fadeeva, EY, Khairullina, ER, Valeyeva, NS, Zaripov, RN, Zaripova, IR \& Kuzmin, NV (2015). Development dynamics study of professional and pedagogical culture of communication in professional activities of teachers. Mediterranean Journal of Social Sciences. 6, (2), 216-225.

Terentyeva IV, Mukhomorova IV, Perezhogina ON, Pugacheva NB, Lunev AN, Akhmetzyanova GN, Lezhnin VV \& Gainullina RR (2016). Development strategy of service sector in conditions of federal states entities autonomy increasing. International Review of Management and Marketing,(6), 1-5.

Terentyeva, IV, Starodubtsev, MP., Timonin, AI., Pugacheva, NB., Zykova, NN., Lunev, AN., Ezhov, SG., \& Starikova, LD., (2016). Assessment of state services quality and availability in the socio-cultural sphere. International Review of Management and Marketing, (6), 1, 122-127.

Ustaomeroglu AA, Aydintan E, Erbay M, Kucuk P \& Sadiklar Z (2015). The impact of basic design studio courses on interior design: KTU model. Procedia - Social and Behavioral Sciences, 197, 1889-1896.

White, M., \& Epston, D., (1990). Narrative Means to Therapeutic Ends. New York: W.W. Norton, 229.

White, M., (2010). Maps of Narrative Practice. Moscow: Genezis.

Winslade, J., \& Monk, G., (2000) Narrative Mediation: A New Approach to Conflict Resolution. San Francisco: Jossey-Bass, 256.

Yepaneshnikov, VV., Pugacheva, NB., Goloshumova, GS., Kuznetsova, VV., Dobrovolskaya, LV., Moiseeva, LV., Garaganov, AV., \& Litvinenko, NA., (2016). Pedagogical management of civil education of research universities students. International Review of Management and Marketing, (6), 2S, 23-27.

Zamaletdinov, RR., Yudina, NP., Lavrentyeva, EI., Savva, LI., \& Pugacheva, NB., (2016). Practical recommendations on the improvement of the effectiveness of anticorruption policy in universities. International Review of Management and Marketing (6) 2, 390-396. 


\section{Turkish Abstract \\ Üniversite Öğrencilerinin İletişim Becerilerinin Geliștirilmesinde Pedagojik Yönetim}

Sosyal etkileşim formları üniversite öğrencierinin iletişim becerilerinin geliştirilmesinin aciliyetini ve önemini vurgulamaktadır. Bu araştırmanın amacı, üniversite öğrencierinin iletişim becerilerinin geliştirilmesinde pedagojik yönetim becerilerinin özelliklerini ortaya çıkarmaktır. Araştırmada kullanılan öncelikli yaklaşım pedagojik yönetim sosyal, psikolojik uyum ve diğer insanlarla etkili iletişim kurmadaki başarı için yaratıcı koşullar oluşturma süreci olarak iletişim becerilerinin geliştirilmesini dikkate alan anlatı yaklaşımıdır. Araştırma sonuçları, pedagojik yönetim yöntemlerini ve bunların etkililik ölçütlerini tanımlamaktadır. Bulgular, insanları anlamanın, onları yeterli bir şekilde değerlendirmenin, empati kurmanın, anlamanın etkin işbirlikli düzenlemelerin ve beceri gelişiminin bireysel benliği koruduğunu göstermektedir.

Anahtar Kelimeler: pedagojik yönetim, anlatı yaklaşımı, eğitimin etkisi, üniversite, yüksek öğretim

\section{French Abstract}

\section{Gestion Pédagogique du Développement de Capacité de Communication d'Étudiants} Universitaires

Le développement de formes d'interaction sociales souligne l'urgence et l'importance du sujet. Le but de l'étude est de découvrir les particularités de gestion pédagogique du développement de capacité de communication des étudiants universitaires. L'approche principale à la recherche était l'approche narrative qui permet de considérer la gestion pédagogique de développement de capacité de communication comme le processus de créer des conditions pour l'adaptation psychologique sociale réussie et l'interaction effective avec des autres personnes. Les résultats de recherche sont l'identification de méthodes pédagogiques de gestion et leurs critères d'efficacité. Les découvertes ont révélé l'arrangement de coopération actif et le développement de compétences : pour percevoir les gens, évaluez-les en juste proportion, sympathisez, comprenez; gardez l'état stable de l'individu soi.

Mots Clés: gestion pédagogique, approche narrative, impact d'enseignement université, enseignement supérieur

\section{Arabic Abstract}

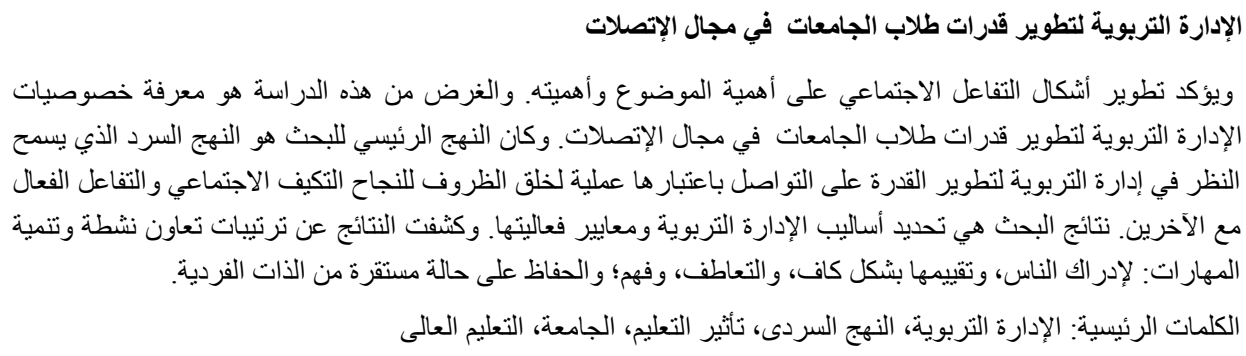




\section{German Abstract \\ Pädagogische Leitung der Universitätsstudenten Kommunikationsfähigkeit Entwicklung}

Die Entwicklung von sozialen Interaktionsformen unterstreicht die Dringlichkeit und Bedeutung des Themas. Der Zweck der Studie ist es, herauszufinden, Besonderheiten der pädagogischen Verwaltung der Universitätsstudenten Kommunikationsfähigkeit Entwicklung. Der führende Ansatz für die Forschung war der Erzählungsansatz, der es ermöglicht, das pädagogische Management der Kommunikationsfähigkeitsentwicklung als Prozess der Schaffung von Bedingungen für eine erfolgreiche sozialpsychologische Anpassung und effektive Interaktion mit anderen Menschen zu betrachten. Die Forschungsergebnisse sind die Identifizierung von pädagogischen Managementmethoden und deren Wirksamkeitskriterien. Die Erkenntnisse zeigten eine aktive Kooperationsvereinbarung und Kompetenzentwicklung: die Menschen wahrzunehmen, angemessen zu beurteilen, zu erfassen, zu verstehen; Behalte den stetigen Zustand des individuellen Selbst.

Schlüsselwörter: pädagogische leitung, erzählung, bildungswirkung, hochschule, hochschulbildung

\section{Malaysian Abstract \\ Pedagogi Pengurusan Pembangunan Keupayaan Komunikasi Pelajar Universiti}

Perkembangan bentuk interaksi sosial menekankan segera dan kepentingan topik. Tujuan kajian ini adalah untuk mengetahui keunikan pengurusan pedagogi pembangunan keupayaan komunikasi pelajar universiti. Pendekatan yang membawa kepada penyelidikan adalah pendekatan naratif yang membolehkan mengingati pengurusan pedagogi pembangunan keupayaan komunikasi sebagai proses mewujudkan syarat-syarat bagi adaptasi psikologi sosial yang berjaya dan interaksi berkesan dengan orang lain. Hasil penyelidikan adalah pengenalan kaedah pengurusan pedagogi dan kriteria keberkesanannya. Dapatan kajian menunjukkan perjanjian kerjasama dan pembangunan kemahiran aktif: untuk melihat orang, menilai mereka dengan secukupnya, menjiwai, memahami; menjaga keadaan mantap diri individu.

Kata Kunci: pengurusan pedagogi, pendekatan naratif, kesan pendidikan, universiti, pendidikan tinggi

\section{Russian Abstract \\ Педагогическое Управление Развитием Коммуникативных Способностей Студентов}

Развитие форм социального взаимодействия подчеркивает актуальность и важность темы. Цель исследования: выявить особенности педагогического управления развитием коммуникативных способностей студентов. Ведущим подходом к исследованию был наративный подход, позволяющий рассматривать педагогическое управление развитием коммуникативных способностей как процесс создания условий для успешной социальнопсихологической адаптации и эффективного взаимодействия $\mathrm{c}$ другими людьми. Результаты исследований - это выявление методов педагогического управления и критериев их эффективности. Выводы показали активное сотрудничество и развитие навыков, таких как: воспринимать людей, оценивать их адекватно, сопереживать, понимать; поддерживать стабильное состояние индивидуальной личности.

Ключевые Слова: педагогический менеджмент, нарративный подход, влияние на образование, университет, высшее образование 